\title{
Purinergic Receptors: Key Mediators of HIV-1 Infection and Inflammation
}

\author{
Talia H. Swartz ${ }^{1 *}$, George R. Dubyak ${ }^{2}$ and Benjamin K. Chen \\ ${ }^{1}$ Division of Infectious Diseases, Icahn School of Medicine at Mount Sinai, New York, NY, USA, ${ }^{2}$ Department of Physiology \\ and Biophysics, Case Western Reserve University, Cleveland, OH, USA
}

Human immunodeficiency virus type 1 (HIV-1) causes a chronic infection that afflicts more than 30 million individuals worldwide. While the infection can be suppressed with potent antiretroviral therapies, individuals infected with HIV-1 have elevated levels of inflammation as indicated by increased $T$ cell activation, soluble biomarkers, and associated morbidity and mortality. A single mechanism linking HIV-1 pathogenesis to this inflammation has yet to be identified. Purinergic receptors are known to mediate inflammation and have been shown to be required for HIV-1 infection at the level of HIV-1 membrane fusion. Here, we review the literature on the role of purinergic receptors in HIV-1 infection and associated inflammation and describe a role for these receptors as potential therapeutic targets.

OPEN ACCESS

Edited by:

Diana Bahia,

Universidade Federal de Minas

Gerais, Brazil

Reviewed by:

Dirk Dittmer,

University of North Carolina at

Chapel Hill, USA

Hridayesh Prakash,

University of Hyderabad, India

*Correspondence:

Talia H. Swartz

talia.swartz@mssm.edu

Specialty section:

This article was submitted to

Microbial Immunology,

a section of the journal

Frontiers in Immunology

Received: 30 June 2015 Accepted: 02 November 2015 Published: 26 November 2015

Citation:

Swartz TH, Dubyak GR and Chen BK (2015) Purinergic Receptors: Key Mediators of HIV-1 Infection and Inflammation.

Front. Immunol. 6:585. doi: 10.3389/fimmu.2015.00585
Keywords: P2X, P2X7, HIV, inflammation mediators, inflammasome, inflammatory cytokines

\section{INTRODUCTION}

Human immunodeficiency virus type 1 (HIV-1) disease afflicts more than 30 million individuals worldwide. The infection remains incurable despite the advent of antiretroviral therapies. Individuals who are infected with HIV-1 can live long lives without infectious complications; however, they experience non-infectious comorbidities known as non-AIDS-associated comorbidities. These are thought to be due to a process of chronic inflammation that occurs despite virologic suppression (1). This phenomenon may account for a wide variety of comorbidities including cognitive decline, cardiovascular disease, and thrombotic disease (2-8). A unifying mechanism has not been identified; however, an emerging literature implicates the role of purinergic receptors, proinflammatory signaling mediators, as important regulators of HIV-1 productive infection. Because these receptors are required for HIV-1 entry, it is hypothesized that they may additionally play a key role in inflammation and underlie comorbidities that shorten the life expectancy of HIV-infected individuals. An understanding of how these receptors may be involved in HIV-1 infection and inflammation would enable the production of novel therapeutics that both antagonize HIV-1 entry and inflammation associated with HIV-1 infection.

\section{HIV-1 AND INFLAMMATION}

Patients with HIV-1 infection have experienced a tremendous leap in life expectancy due to the advent of effective antiretroviral therapy (ART). The result has been that individuals are living longer and now experiencing comorbidities similar to disease processes found in the general population. In fact, a study in 2008 demonstrated that only $10 \%$ of deaths in HIV-infected individuals were related to AIDS-defining illnesses while other causes included non-AIDS-defining malignancies, cardiovascular disease, liver disease, and others (9). There are certain conditions that appear to develop 
in HIV-infected individuals at an earlier age than the general population. This phenomenon has been referred to as "accelerated aging" and is thought to relate to chronic inflammation and immunosenescence. There are multiple possible explanations that may include ART toxicity, lifestyle (i.e., tobacco, alcohol, and IV drug abuse), as well as HIV-1 infection itself $(10,11)$.

How might HIV-infected individuals develop comorbidities associated with chronic inflammation? There are multiple possible explanations. HIV-1 infection causes a chronic viral infection that results in selective $\mathrm{CD}^{+} \mathrm{T}$ cell depletion which has a major impact on lymphocytes in the gastrointestinal tract $(12,13)$. Chronic HIV-1 infection leads to reduced integrity of the mucosal epithelium causing bacterial translocation. This process is proposed to play a key role in chronic inflammation in HIV-1 disease (14-16). High bacterial lipopolysaccharide (LPS) levels in HIV-infected individuals are associated with elevated inflammatory biomarkers (17). Abnormally high levels of T cell activation can persist despite years of virologic suppression (18), and these individuals have lower levels of $\mathrm{CD} 4^{+}$reconstitution $(19,20)$. Elevated soluble inflammatory biomarkers are detected in these individuals including markers of type I interferon (1), monocyte activation (21), and inflammation and coagulation (22). Specifically, levels of IL-6, hsCRP, and D-dimer persist at elevated levels in HIV-infected patients. There are multiple proposed mechanisms that may elevated immune activation even when virus is suppressed (1). One is that low levels of viral replication may continue, but with viral loads below the limit of detection. These levels may stimulate systemic inflammation; however, no studies support a role for intensification of therapy to reduce inflammation $(23,24)$. The importance of this chronic inflammation lies in its associations with comorbidities that account for the major mortality in individuals infected with HIV-1. These include cardiovascular disease, neurological decline, end organ dysfunction, and thrombotic events (2-8). Even with highly active antiretroviral therapy, which is effective at achieving virologic suppression, individuals who are chronically infected with HIV-1 have elevated inflammatory biomarkers and display innate immune activation and immune dysfunction that does not normalize with therapy (25). No unifying mechanism thus far has connected HIV-1 infection to the regulation of proinflammatory signaling.

\section{OVERVIEW OF PURINERGIC RECEPTORS}

Purinergic receptors are ubiquitously expressed in mammalian cells. In 1970s, extracellular nucleotide became recognized as an important mediator of cellular signaling (26). A large literature describes the role of purinergic receptors as detectors of extracellular adenosine and adenosine triphosphate (ATP) that activate intracellular signaling events (27). These receptors can be characterized into two classes, the $\mathrm{P} 1$ adenosine receptors and $\mathrm{P} 2 \mathrm{ATP} / \mathrm{ADP}$ receptors. $\mathrm{P} 2$ receptors are further divided into two categories: the P2X and P2Y subtypes. P2X receptors are ATP-gated plasma membrane channels that can be formed by a trimeric assembly of seven different subunits (P2X1-P2X7) which assemble as homotrimers or heterotrimers $(28,29)$.
P2X receptors are key regulators of a number of important physiological processes including neuronal synaptic and modulation, cell death and proliferation, cell and organ motility, and infection and inflammation (30-34). P2X receptors are ATP-gated non-selective cation channels. An agonist, ATP or other nucleotides, binds to the extracellular portion, inducing conformational changes that triggers channel opening and cation flux $(28,35)$. Some of these receptors can dilate to a larger pore, thus increasing permeability to large organic molecules (36-38). This occurs with prolonged exposure to agonist; other subtypes, notably P2X1, undergo fast desensitization with prolonged ATP exposure, resulting in closure of the channel $(39,40)$. Functional P2X receptors assemble as either homotrimers or heterotrimers, each subunit of which contains two transmembrane domains, a large extracellular loop containing 10 conserved cysteine residues and glycosylation sites, and intracellular $\mathrm{N}$ and $\mathrm{C}$ termini containing consensus phosphorylation sites $(29,31,41-43)$. P2X7 specifically has a large pore that assembles as a homotrimer, by contrast to some other $\mathrm{P} 2 \mathrm{X}$ receptors. Roles for the $\mathrm{P} 2 \mathrm{X} 7$ subtype are well-characterized in the innate immune response and include proinflammatory cytokine activation, antigen presentation, and lymphocyte proliferation and differentiation (44-46). P2X7 receptor activation requires submillimolar ATP concentrations which are only transiently released extracellular compartments in response to acute cell death or injury (28). Sustained activation of P2X7 can result in large pore opening which enables passage of molecules up to $900 \mathrm{Da}$ that to eventually induce cell death $(31,47)$.

$\mathrm{P} 2 \mathrm{Y}$ receptors function widely across diverse physiological systems and have roles in clotting, hormone secretion, vasodilatation, neuromodulation, cell migration, cell proliferation and cell death, wound healing, and immune response $(26,27,34,37$, 48-50). The P2Y subtypes are of G protein-coupled receptors. They consist of seven transmembrane domains with an extracellular N-terminus and an intracellular C-terminus (48, 51, 52). Activation of the receptor results in $\mathrm{G}$ protein dissociation into $\alpha$ and $\beta \gamma$ subunits which activates downstream effector molecules. A large sequence diversity encodes for diverse pharmacological profiles among these receptors (53). There are eight $\mathrm{P} 2 \mathrm{Y}$ monomer subtypes. P2Y1, P2Y2, P2Y4, and P2Y6 couple to $\mathrm{G}_{\mathrm{q}}$ to activate phospholipase $\mathrm{C}$ and P2Y12, P2Y13, and P2Y14 couple to $\mathrm{G}_{\mathrm{i}}$ to inhibit adenylyl cyclase and activate GIRK-family $\mathrm{K}^{+}$channels. P2Y11 can couple to both $G_{\mathrm{q}}$ and $G_{\mathrm{s}}$ and trigger increases in intracellular $\mathrm{Ca}^{2+}$ and in cAMP levels.

\section{PURINERGIC SIGNALING IN INFLAMMATION}

Purinergic receptors can be found in a wide variety of leukocyte sub-types, notably lymphocytes, monocyte/macrophages, and dendritic cells $(29,44,54-56)$. They are critical mediators of the innate immune response in a variety of different disease states including rheumatoid arthritis, transplant rejection, and inflammatory bowel disease (57-60). Nucleotides are known mediators of innate immune cell function including cell migration $(61,62)$. Extracellular nucleotides, such as ATP, are released by metabolic stress, ischemia, hypoxia, and inflammation that leads to cell 
death and the further release of intracellular contents into surrounding tissue $(26,33)$. Release of ATP of through channels can signal through purinergic receptors to modify cellular orientation, cytoskeletal rearrangement, chemotaxis, and cell migration $(63,64)$. Studies have supported a role for signaling of these receptors in immune function of macrophages, neutrophils, B lymphocytes, and T lymphocytes. Thymocytes can undergo programed cell death in response to purinergic activation and nucleotides have been implicated in fate-determination during T cell development (65). Extracellular ATP bind these to purinergic receptor which can activate T cells through extracellular calcium influx, p38 MAPK activation, and IL-2 secretion (66-69). ATP can also activate $\gamma \delta \mathrm{T}$ cells through the P2X4 receptor, while $\mathrm{P} 2 \mathrm{X} 7$ activation can promote differentiation of $\mathrm{T}$ into proinflammatory $\mathrm{TH}_{17}$ effector cells $(45,70)$. The P2X1, $\mathrm{P} 2 \mathrm{X} 4$, and P2X7 subtypes are most highly expressed on leukocytes, and literature implicates the P2X7 subtype specifically in inflammatory signaling (71-74).

P2X7 receptors are the most highly expressed P2X receptor subtype in innate immune cells $(44,71,75)$. They activate proinflammatory cytokine production $(44,76)$ and can trigger activation of the inflammasome. The inflammasome is a central scaffold protein complex that serves to coordinate interaction with caspase molecules which cleave precursor protein substrates into immunomodulatory products. Activation of $\mathrm{P} 2 \mathrm{X} 7$ results in massive $\mathrm{K}^{+}$efflux, and this change in ionic strength signals to the processing of procaspase-1 (77). Mature caspase- 1 cleaves prointerleukin-1 $\beta$ (pro-IL-1 $\beta$ ) into interleukin-1 $\beta$ (IL-1 $\beta$ ) which is released into the cytoplasm $(23,30)$. Signaling takes place as part of a two component signal which requires an initial signal, such as a toll-like receptor activation via bacterial or viral ligands. Activation of P2X7 can serve as a second signal, inducing assembly of the inflammasome complex which activates caspase-1, with consequent cleavage of pro-IL- $1 \beta$ to mature secretory IL- $1 \beta$ (78). Inflammasome activation is also known to mediate pyroptosis, a mode of inflammatory programed cell death in myeloid and lymphoid leukocytes (79-81).

\section{PURINERGIC RECEPTORS IN HIV-1 INFECTION}

Because purinergic receptor signaling can clearly mediate inflammatory responses, these receptors are likely to be activated in response to infections. As HIV-1 is a viral infection marked by chronic inflammation, this signaling pathway might serve as an important intersection between viral infection and chronic inflammation. Purinergic signaling is involved in several infectious processes $(82,83)$, including bacterial and mycobacterial [Mycobacterium tuberculosis (84-87) and Chlamydia infections (88)], protozoal infections including Leishmania $(89,90)$ and Toxoplasma $(91,92)$, and viral infections including respiratory viral infections $(93,94)$, hepatitis B and hepatitis delta virus (95, 96), hepatitis C virus (97, 98), Cytomegalovirus (99), and HIV-1 (100-105).

Adenosine receptors have been implicated in HIV pathogenesis as Nikolova et al. reported an association between CD39 expression and AIDS progression (106). CD39 is an ectoenzyme that breaks down ATP to AMP which in turn, is hydrolyzed by CD73 to generate adenosine that signals through purinergic A1/2-type receptors. $T_{\text {reg }}$ inhibition was shown to be mitigated by CD39 downregulation with associated elevated levels of A2A receptor on $\mathrm{T}$ cells of infection patients. The authors also noted that $\mathrm{T}_{\text {reg }}$ CD39 expansion was associated with elevated immune activation and that a CD39 gene polymorphism was associated with reduced CD39 expression and a delay in the onset of AIDS.

A role for extracellular ATP signaling has been proposed in HIV-1 infection. Sorrell et al. observed that treatment with a non-selective P2X antagonist reduced neurotoxic effects of opiates with generated in the context of HIV Tat activity which suggested that $\mathrm{P} 2 \mathrm{X}$ receptors might modulate neurotoxicity. Those authors proposed that $\mathrm{P} 2 \mathrm{X}$ inhibitors may serve to reduce neuroinflammation and neurodegeration in neuro-AIDS in the context of opiate abuse (107). Tovar and colleagues found that ATP released from HIV-infected macrophages can reduce dendritic spine density through purinergic-dependent glutamate receptor down-modulation. They proposed that neuronal injury in HIV-infected patients may relate to purinergic signaling and ATP release from macrophages that can impact on glutamate regulation (108).

Recent studies have raised the possibility that purinergic receptors as host proteins may be directly related to HIV-1 pathogenesis. Seror et al. demonstrated that infection of human lymphocytes with HIV-1 can induce ATP release and that this event is required for infection (104). Pharmacologic inhibition of purinergic receptors reduced HIV-mediated cell death and HIV infection. Non-selective purinergic receptors antagonists inhibited CCR5 and CXCR4-tropic HIV-1 productive infection in lymphocytes and CCR5-tropic virus in dendritic cells and macrophages. This study found that the selective depletion of P2Y2 with small interfering RNA diminished the HIV-induced inflammatory response and also resulted in mildly elevated levels of P2Y2 in HIV-infected patient tissue compared with uninfected control tissue. Immunofluorescence analyses indicated that P2Y2 and the ATP-release channel pannexin-1 appeared to polarize to the virologic synapse; the latter is the interface between an infected donor cell and an uninfected target cell where cell-to-cell transfer and infection takes place $(109,110)$.

Hazleton et al. demonstrated a key role for purinergic receptors in HIV-1 replication in macrophages (102). Macrophages are critical to $\mathrm{HIV}-1$ pathogenesis as they may represent key reservoirs and can mediate immune responses through production of proinflammatory cytokines. The authors demonstrated that selective pharmacologic inhibition of P2X1, P2X7, and P2Y1 resulted in dose-dependent inhibition of HIV-1 infection. Using a beta-lactamase fusion assay, they observed a requirement for $\mathrm{P} 2 \mathrm{X} 1$ in HIV-1 fusion in macrophages and that activation of P2X1 results in calcium flux that enables HIV-1 entry (111). More recently, Giroud et al. described a role for P2X1 (112) that involved block age of binding of HIV-1 to the chemokine receptors CCR5 and CXCR4. The group corroborated findings that inhibition of P2X1 with an inhibitor did not interfere with attachment but did inhibit fusion downstream of CD4 binding prior to coreceptor engagement. 
Swartz et al. demonstrated that non-selective $\mathrm{P} 2 \mathrm{X}$ receptor inhibitors inhibit HIV-1 infection of CD4 ${ }^{+}$lymphocytes by cellto-cell and cell-free mechanisms (105). Using a systematic pharmacologic screening approach, it was found that only antagonists of a P2X subclass of purinergic receptors mediated inhibition of HIV-1 viral membrane fusion and productive infection of T cells. Because P2X inhibitors are a major focus of current pharmaceutical development for chronic inflammation, pain, and depression $(59,113,114)$, this drug class has variants that may be assessed for both HIV inhibitory and inflammation inhibitory activities.

Orellana and colleagues observed that the function of the pannexin-1 ATP-release hemichannel was transiently increased during early infection with both R5 and X4 tropic HIV-1 and that HIV-1 envelope binding to CD4 and coreceptors (both CXCR4 and CCR5) activates pannexin-1 channel opening as a feedforward signal which can enable HIV-1 internalization in $\mathrm{CD}^{+}$ $\mathrm{T}$ cells (103). This study highlights the pannexin- 1 hemichannel and associated factors, i.e., purinergic receptors as host factors that play important roles in early stages of HIV-1 entry (115). The role of purinergic inhibitors in HIV-1 disease is currently being investigated (116).
Most recently, Graziano et al. demonstrated that extracellular ATP induced rapid release of HIV-1 particles from human monocyte-derived macrophages that was P2X7 dependent (117). They hypothesized that virion egress may be additionally regulated by $\mathrm{P} 2 \mathrm{X} 7$ function.

Definitive data are still lacking regarding which $\mathrm{P} 2 \mathrm{X}$ receptor(s) are specifically required by HIV-1 and how purinergic signaling facilitates HIV-1 entry. Additionally, it is unknown whether HIV-1 infection activates other P2X7 signaling pathways, notably those involved in the NLRP3 inflammasome, which mediates IL- $1 \beta$ release. Elevated IL-1 $\beta$ is observed in HIV-infected patients (118-121), although these studies do have not directly link HIV-1 infection to inflammasome activation. Intriguing studies in $\mathrm{CD}^{+} \mathrm{T}$ cells found that pathogen sensor IFI-16 recognition of HIV-1 DNA can activate the inflammasome that induces proinflammatory lymphocyte programed cell death known as pyroptosis (122-125). This may represent a mechanism for $\mathrm{CD}^{+}{ }^{+} \mathrm{T}$ cell depletion in HIV-1 disease and AIDS $(126,127)$. We present a model for the role of $\mathrm{HIV}-1$ and purinergic signaling in Figure 1. This posits that HIV-1 entry results in the activation of $\mathrm{P} 2 \mathrm{X}$ receptors and facilities fusion. This event may also trigger

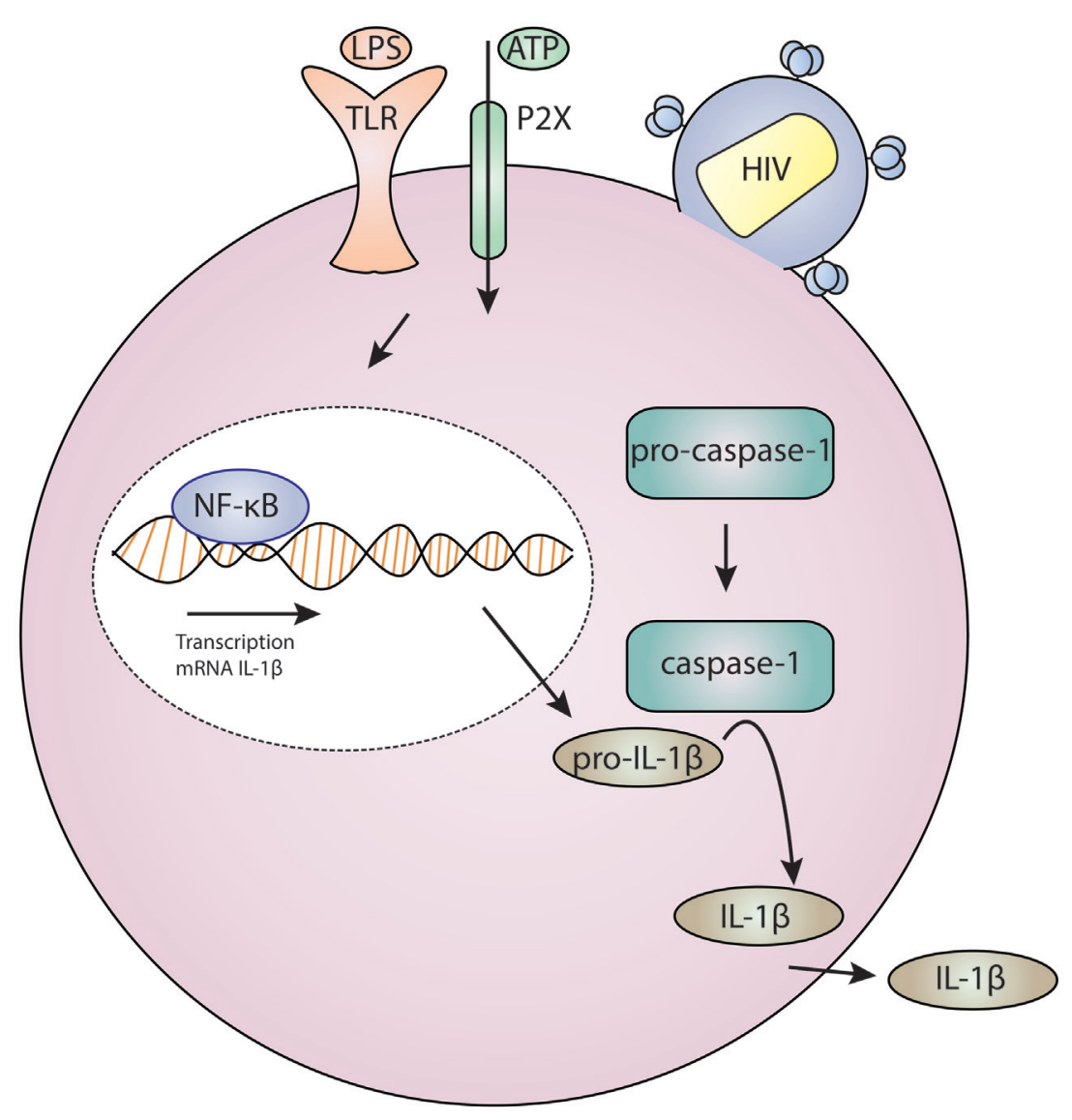

FIGURE 1 | Model for HIV infection and purinergic receptor signaling in a lymphocyte or macrophage/monocyte. HIV-1 attaches to a cell, and this is associated with P2X activation which results in cation and potentially large molecule flux. Concurrent toll-like receptor (TLR) activation by ligands, such as bacterial lipopolysaccharide (LPS), results in gene regulation through NF-kB. These two signals - TLR and P2X - are required for inflammasome activation which results in cleavage of procaspase- 1 to caspase- 1 which activates IL-1 $\beta$ which is then secreted. 
TABLE 1 | P2X7 inhibitors in clinical trials.

\begin{tabular}{|c|c|c|c|c|}
\hline Drug & Company & Phase & Endpoint & Reference \\
\hline EVT 401 & Evotec & I & $\begin{array}{l}\text { Safety inhibition } \\
\text { of ATP-stimulated } \\
\text { IL-1 } 1 \beta \text { release }\end{array}$ & (133) \\
\hline AZ9056 & AstraZeneca & Ila & Safety, ACR20a & (58) \\
\hline CE-224,535 & Pfizer & Ila & Safety, ACR20 & $(59,134)$ \\
\hline GSK1482160 & GlaxoSmithKline & 1 & Safety & $(113,135)$ \\
\hline
\end{tabular}

${ }^{a}$ American College of Rheumatology 20\% response criteria (136).

inflammasome activation which results in maturation and release of IL-1 $\beta$; this in turn drives inflammation and inflammatory cell death, thus depleting neighboring $\mathrm{CD} 4^{+} \mathrm{T}$ cells and contributing to systemic inflammation.

Novel antiretroviral therapies that target both HIV-1 productive infection as well as inflammation would be helpful in treating HIV-associated comorbidities. Because targeting purinergic receptors appears to be equivalently effective at blocking cell-free and cell-to-cell infection, these are attractive targets; inhibition of cell-to-cell infection with some ART can exhibit diminished efficacy (128-130). Finally, a recent study suggests that nucleoside reverse transcriptase inhibitors can inhibit inflammasome activation and reduce levels of IL-1 $\beta$ production (131). This suggests an important connection between HIV-1 pathogenesis and underlying inflammation through inflammasome activation.

Well-studied purinergic compounds in advanced stages of therapeutic development are the P2X7 antagonists. Various inhibitors, such as KN-62, PPADS, oxidized ATP, brilliant Blue G, AZ9056, A 740003, and A 438079, have been tested in inflammatory and neurological diseases (132). Several highly selective $\mathrm{P} 2 \mathrm{X} 7$ receptor antagonists have been tested in clinical trials for safety for inflammatory pain conditions, specifically rheumatoid arthritis (Table 1). All drugs tested have demonstrated safety but have yet to show efficacy at reducing inflammatory pain.

While these drugs have not demonstrated efficacy in reducing neuropathic pain, there is potential for their applications in the

\section{REFERENCES}

1. French MA, King MS, Tschampa JM, da Silva BA, Landay AL. Serum immune activation markers are persistently increased in patients with HIV infection after 6 years of antiretroviral therapy despite suppression of viral replication and reconstitution of CD4+ T cells. J Infect Dis (2009) 200:1212-5. doi:10.1086/605890

2. Tenorio AR, Zheng Y, Bosch RJ, Krishnan S, Rodriguez B, Hunt PW, et al. Soluble markers of inflammation and coagulation but not T-cell activation predict non-AIDS-defining morbid events during suppressive antiretroviral treatment. J Infect Dis (2014) 210:1248-59. doi:10.1093/ infdis/jiu254

3. Hunt PW, Sinclair E, Rodriguez B, Shive C, Clagett B, Funderburg N, et al. Gut epithelial barrier dysfunction and innate immune activation predict mortality in treated HIV infection. J Infect Dis (2014) 210:1228-38. doi:10.1093/infdis/jiu238

4. Cain LE, Logan R, Robins JM, Sterne JA, Sabin C, Bansi L, et al. When to initiate combined antiretroviral therapy to reduce mortality and AIDS-defining illness in HIV-infected persons in developed modulation of inflammation related to infection. Of note, suramin is a well-described antiprotozoal agent that also has reverse transcription inhibitor activity in vitro against HIV-1 (137). In the 1980s, suramin was proposed as an ART and was given to 98 patients with AIDS (138). The study was ineffective at demonstrating survival advantage in the treated patients, largely because the patients had a high burden of disease and because the compound is toxic. Current drug development aims for compounds with a lower molecular weight that are moderately lipophilic (132). We propose that testing these agents may yield novel classes of anti-infective drugs that can function both to reduce viral replication and associated inflammation. An important goal in this area is to clarify how purinergic receptor antagonists block HIV-1 entry and to determine the role of purinergic signaling pathways in HIV-1 pathogenesis. The development of drugs that target these pathways may aid in treatment and prevention of HIV-1 disease and associated comorbidities.

\section{CONCLUSION}

Human immunodeficiency virus type 1 disease remains incurable, and as the affected population ages, patients will experience sequelae of chronic inflammation. As ART is still ineffective at eliminating this inflammation, novel therapies and a clearer understanding of the mechanisms that induce inflammation are necessary for improving long-term health of HIV-infected patients. An intriguing convergence of purinergic signaling with HIV-1 infectious pathways and inflammatory pathways indicates that these pathways may be central to disease pathogenesis. Understanding of the mechanisms that underlie such inflammation may enable targeted therapies that are more effective at enhancing the survival of $\mathrm{HIV}$-infected patients by reducing chronic HIV-induced inflammation.

\section{FUNDING}

This work was funded by the National Center for Advancing Translational Science KL2TR00006 and the National Institute of General Medical Sciences GM36387.

countries: an observational study. Ann Intern Med (2011) 154:509-15 doi:10.7326/0003-4819-154-8-201104190-00001

5. Guaraldi G, Orlando G, Zona S, Menozzi M, Carli F, Garlassi E, et al. Premature age-related comorbidities among HIV-infected persons compared with the general population. Clin Infect Dis (2011) 53:1120-6. doi:10.1093/ cid/cir627

6. Ghiringhelli F, Apetoh L, Tesniere A, Aymeric L, Ma Y, Ortiz C, et al. Activation of the NLRP3 inflammasome in dendritic cells induces IL-1betadependent adaptive immunity against tumors. Nat Med (2009) 15:1170-8. doi: $10.1038 / \mathrm{nm} .2028$

7. Bassett IV, Freedberg KA, Walensky RP. Two drugs or three? Balancing efficacy, toxicity, and resistance in postexposure prophylaxis for occupational exposure to HIV. Clin Infect Dis (2004) 39:395-401. doi:10.1086/422459

8. Sigel K, Dubrow R, Silverberg M, Crothers K, Braithwaite S, Justice A. Cancer screening in patients infected with HIV. Curr HIV/AIDS Rep (2011) 8:142-52. doi:10.1007/s11904-011-0085-5

9. Lifson AR; INSIGHT Cause of Death Writing Group, Belloso WH, Carey C, Davey RT, Duprez D, et al. Determination of the underlying cause of death 
in three multicenter international HIV clinical trials. HIV Clin Trials (2008) 9:177-85. doi:10.1310/hct0903-177

10. Aberg JA. Aging, inflammation, and HIV infection. Top Antivir Med (2012) 20:101-5.

11. Deeks SG. HIV infection, inflammation, immunosenescence, and aging. Annu Rev Med (2011) 62:141-55. doi:10.1146/annurev-med-042909-093756

12. Brenchley JM, Schacker TW, Ruff LE, Price DA, Taylor JH, Beilman GJ, et al. CD4+ T cell depletion during all stages of HIV disease occurs predominantly in the gastrointestinal tract. J Exp Med (2004) 200:749-59. doi:10.1084/ jem. 20040874

13. Mehandru S, Poles MA, Tenner-Racz K, Horowitz A, Hurley A, Hogan C, et al. Primary HIV-1 infection is associated with preferential depletion of CD4+ T lymphocytes from effector sites in the gastrointestinal tract. J Exp Med (2004) 200:761-70. doi:10.1084/jem.20041196

14. Hazenberg MD, Otto SA, van Benthem BH, Roos MT, Coutinho RA, Lange JM, et al. Persistent immune activation in HIV-1 infection is associated with progression to AIDS. AIDS (2003) 17:1881-8. doi:10.1097/00002030-200309050-00006

15. Deeks SG, Kitchen CM, Liu L, Guo H, Gascon R, Narvaez AB, et al. Immune activation set point during early HIV infection predicts subsequent CD4+ T-cell changes independent of viral load. Blood (2004) 104:942-7. doi:10.1182/blood-2003-09-3333

16. Brenchley JM, Price DA, Douek DC. HIV disease: fallout from a mucosal catastrophe? Nat Immunol (2006) 7:235-9. doi:10.1038/ni1316

17. Vassallo M, Mercie P, Cottalorda J, Ticchioni M, Dellamonica P. The role of lipopolysaccharide as a marker of immune activation in HIV-1 infected patients: a systematic literature review. Virol J (2012) 9:174. doi:10.1186/1743-422X-9-174

18. Valdez H, Connick E, Smith KY, Lederman MM, Bosch RJ, Kim RS, et al. Limited immune restoration after 3 years' suppression of HIV-1 replication in patients with moderately advanced disease. AIDS (2002) 16:1859-66. doi:10.1097/00002030-200209270-00002

19. Hunt PW, Martin JN, Sinclair E, Bredt B, Hagos E, Lampiris H, et al. T cell activation is associated with lower CD4+ T cell gains in human immunodeficiency virus-infected patients with sustained viral suppression during antiretroviral therapy. J Infect Dis (2003) 187:1534-43. doi:10.1086/374786

20. Massanella M, Negredo E, Perez-Alvarez N, Puig J, Ruiz-Hernandez R, Bofill $\mathrm{M}$, et al. CD4 T-cell hyperactivation and susceptibility to cell death determine poor CD4 T-cell recovery during suppressive HAART. AIDS (2010) 24:959-68. doi:10.1097/QAD.0b013e328337b957

21. Burdo TH, Lentz MR, Autissier P, Krishnan A, Halpern E, Letendre S, et al. Soluble CD163 made by monocyte/macrophages is a novel marker of HIV activity in early and chronic infection prior to and after anti-retroviral therapy. J Infect Dis (2011) 204:154-63. doi:10.1093/infdis/jir214

22. Neuhaus J, Jacobs DR Jr, Baker JV, Calmy A, Duprez D, La Rosa A, et al. Markers of inflammation, coagulation, and renal function are elevated in adults with HIV infection. J Infect Dis (2010) 201:1788-95. doi:10.1086/652749

23. Dinoso JB, Kim SY, Wiegand AM, Palmer SE, Gange SJ, Cranmer L, et al. Treatment intensification does not reduce residual HIV-1 viremia in patients on highly active antiretroviral therapy. Proc Natl Acad Sci U S A (2009) 106:9403-8. doi:10.1073/pnas.0903107106

24. Hatano H, Hayes TL, Dahl V, Sinclair E, Lee TH, Hoh R, et al. A randomized, controlled trial of raltegravir intensification in antiretroviral-treated, HIVinfected patients with a suboptimal CD4+ T cell response. J Infect Dis (2011) 203:960-8. doi:10.1093/infdis/jiq138

25. Lederman MM, Calabrese L, Funderburg NT, Clagett B, Medvik K, Bonilla $\mathrm{H}$, et al. Immunologic failure despite suppressive antiretroviral therapy is related to activation and turnover of memory CD4 cells. J Infect Dis (2011) 204:1217-26. doi:10.1093/infdis/jir507

26. Burnstock G. Purinergic signalling: its unpopular beginning, its acceptance and its exciting future. Bioessays (2012) 34:218-25. doi:10.1002/ bies. 201100130

27. Burnstock G. Purinergic signalling: pathophysiology and therapeutic potential. Keio J Med (2013) 62:63-73. doi:10.2302/kjm.2013-0003-RE

28. North RA. Molecular physiology of P2X receptors. Physiol Rev (2002) 82:1013-67. doi:10.1152/physrev.00015.2002
29. Burnstock G, Knight GE. Cellular distribution and functions of P2 receptor subtypes in different systems. Int Rev Cytol (2004) 240:31-304. doi:10.1016/ S0074-7696(04)40002-3

30. Dubyak GR. Signal transduction by P2-purinergic receptors for extracellular ATP. Am J Respir Cell Mol Biol (1991) 4:295-300. doi:10.1165/ajrcmb/4.4.295

31. Surprenant A, North RA. Signaling at purinergic P2X receptors. Annu Rev Physiol (2009) 71:333-59. doi:10.1146/annurev.physiol.70.113006.100630

32. Khakh BS, North RA. P2X receptors as cell-surface ATP sensors in health and disease. Nature (2006) 442:527-32. doi:10.1038/nature04886

33. Burnstock G, Kennedy C. P2X receptors in health and disease. Adv Pharmacol (2011) 61:333-72. doi:10.1016/B978-0-12-385526-8.00011-4

34. Burnstock G. Purinergic signalling and disorders of the central nervous system. Nat Rev Drug Discov (2008) 7:575-90. doi:10.1038/nrd2605

35. Khakh BS. Molecular physiology of P2X receptors and ATP signalling at synapses. Nat Rev Neurosci (2001) 2:165-74. doi:10.1038/35058521

36. Khakh BS, Bao XR, Labarca C, Lester HA. Neuronal P2X transmitter-gated cation channels change their ion selectivity in seconds. Nat Neurosci (1999) 2:322-30. doi:10.1038/7233

37. Khakh BS, Lester HA. Dynamic selectivity filters in ion channels. Neuron (1999) 23:653-8. doi:10.1016/S0896-6273(01)80025-8

38. Virginio C, MacKenzie A, Rassendren FA, North RA, Surprenant A. Pore dilation of neuronal P2X receptor channels. Nat Neurosci (1999) 2:315-21. doi:10.1038/7225

39. Jarvis MF, Khakh BS. ATP-gated P2X cation-channels. Neuropharmacology (2009) 56:208-15. doi:10.1016/j.neuropharm.2008.06.067

40. Rettinger J, Schmalzing G. Activation and desensitization of the recombinant P2X1 receptor at nanomolar ATP concentrations. J Gen Physiol (2003) 121:451-61. doi:10.1085/jgp.200208730

41. Coddou C, Yan Z, Obsil T, Huidobro-Toro JP, Stojilkovic SS. Activation and regulation of purinergic P2X receptor channels. Pharmacol Rev (2011) 63:641-83. doi:10.1124/pr.110.003129

42. Erb L, Liao Z, Seye CI, Weisman GA. P2 receptors: intracellular signaling. Pflugers Arch (2006) 452:552-62. doi:10.1007/s00424-006-0069-2

43. Nicke A, Baumert HG, Rettinger J, Eichele A, Lambrecht G, Mutschler E, et al. P2X1 and P2X3 receptors form stable trimers: a novel structural motif of ligand-gated ion channels. EMBO J (1998) 17:3016-28. doi:10.1093/ emboj/17.11.3016

44. Ferrari D, Pizzirani C, Adinolfi E, Lemoli RM, Curti A, Idzko M, et al. The P2X7 receptor: a key player in IL-1 processing and release. J Immunol (2006) 176:3877-83. doi:10.4049/jimmunol.176.7.3877

45. Schenk U, Frascoli M, Proietti M, Geffers R, Traggiai E, Buer J, et al. ATP inhibits the generation and function of regulatory $\mathrm{T}$ cells through the activation of purinergic P2X receptors. Sci Signal (2011) 4:ra12. doi:10.1126/ scisignal. 2001270

46. Junger WG. Immune cell regulation by autocrine purinergic signalling. Nat Rev Immunol (2011) 11:201-12. doi:10.1038/nri2938

47. Browne LE, Compan V, Bragg L, North RA. P2X7 receptor channels allow direct permeation of nanometer-sized dyes. J Neurosci (2013) 33:3557-66. doi:10.1523/JNEUROSCI.2235-12.2013

48. von Kugelgen I, Harden TK. Molecular pharmacology, physiology, and structure of the P2Y receptors. Adv Pharmacol (2011) 61:373-415. doi:10.1016/ B978-0-12-385526-8.00012-6

49. Wang ZX, Nakayama T, Sato N, Izumi Y, Kasamaki Y, Ohta M, et al. Association of the purinergic receptor P2Y, G-protein coupled, 2 (P2RY2) gene with myocardial infarction in Japanese men. Circ J (2009) 73:2322-9. doi:10.1253/circj.CJ-08-1198

50. Burnstock G. Purinergic signaling and vascular cell proliferation and death. Arterioscler Thromb Vasc Biol (2002) 22:364-73. doi:10.1161/hq0302.105360

51. Boarder MR, Weisman GA, Turner JT, Wilkinson GF. G protein-coupled P2 purinoceptors: from molecular biology to functional responses. Trends Pharmacol Sci (1995) 16:133-9. doi:10.1016/S0165-6147(00)89001-X

52. Barnard EA. The transmitter-gated channels: a range of receptor types and structures. Trends Pharmacol Sci (1996) 17:305-9. doi:10.1016/0165-6147(96)10041-9

53. von Kugelgen I. Pharmacological profiles of cloned mammalian P2Yreceptor subtypes. Pharmacol Ther (2006) 110:415-32. doi:10.1016/j. pharmthera.2005.08.014 
54. Collo G, Neidhart S, Kawashima E, Kosco-Vilbois M, North RA, Buell G. Tissue distribution of the P2X7 receptor. Neuropharmacology (1997) 36:1277-83. doi:10.1016/S0028-3908(97)00140-8

55. Di Virgilio F. Liaisons dangereuses: $\mathrm{P} 2 \mathrm{X}(7)$ and the inflammasome. Trends Pharmacol Sci (2007) 28:465-72. doi:10.1016/j.tips.2007.07.002

56. Linden J. Regulation of leukocyte function by adenosine receptors. $A d v$ Pharmacol (2011) 61:95-114. doi:10.1016/B978-0-12-385526-8.00004-7

57. Eltzschig HK, Sitkovsky MV, Robson SC. Purinergic signaling during inflammation. N Engl J Med (2012) 367:2322-33. doi:10.1056/NEJMra1205750

58. Keystone EC, Wang MM, Layton M, Hollis S, McInnes IB, Team DCS. Clinical evaluation of the efficacy of the P2X7 purinergic receptor antagonist AZD9056 on the signs and symptoms of rheumatoid arthritis in patients with active disease despite treatment with methotrexate or sulphasalazine. Ann Rheum Dis (2012) 71:1630-5. doi:10.1136/annrheumdis-2011-143578

59. Stock TC, Bloom BJ, Wei N, Ishaq S, Park W, Wang X, et al. Efficacy and safety of CE-224,535, an antagonist of P2X7 receptor, in treatment of patients with rheumatoid arthritis inadequately controlled by methotrexate. J Rheumatol (2012) 39:720-7. doi:10.3899/jrheum.110874

60. Vergani A, Tezza S, D’Addio F, Fotino C, Liu K, Niewczas M, et al. Long-term heart transplant survival by targeting the ionotropic purinergic receptor P2X7. Circulation (2013) 127:463-75. doi:10.1161/ CIRCULATIONAHA.112.123653

61. Idzko M, Dichmann S, Ferrari D, Di Virgilio F, la Sala A, Girolomoni G, et al. Nucleotides induce chemotaxis and actin polymerization in immature but not mature human dendritic cells via activation of pertussis toxin-sensitive P2y receptors. Blood (2002) 100:925-32. doi:10.1182/blood.V100.3.925

62. Mei L, Du W, Gao W, Mei QB. Purinergic signaling: a novel mechanism in immune surveillance. Acta Pharmacol Sin (2010) 31:1149-53. doi:10.1038/ aps. 2010.128

63. Kronlage M, Song J, Sorokin L, Isfort K, Schwerdtle T, Leipziger J, et al. Autocrine purinergic receptor signaling is essential for macrophage chemotaxis. Sci Signal (2010) 3:ra55. doi:10.1126/scisignal.2000588

64. McDonald B, Pittman K, Menezes GB, Hirota SA, Slaba I, Waterhouse CC, et al. Intravascular danger signals guide neutrophils to sites of sterile inflammation. Science (2010) 330:362-6. doi:10.1126/science.1195491

65. Frascoli M, Marcandalli J, Schenk U, Grassi F. Purinergic P2X7 receptor drives $\mathrm{T}$ cell lineage choice and shapes peripheral gammadelta cells. J Immunol (2012) 189:174-80. doi:10.4049/jimmunol.1101582

66. Baricordi OR, Ferrari D, Melchiorri L, Chiozzi P, Hanau S, Chiari E, et al. An ATP-activated channel is involved in mitogenic stimulation of human $\mathrm{T}$ lymphocytes. Blood (1996) 87:682-90.

67. Yip L, Woehrle T, Corriden R, Hirsh M, Chen Y, Inoue Y, et al. Autocrine regulation of T-cell activation by ATP release and $\mathrm{P} 2 \mathrm{X} 7$ receptors. FASEB J (2009) 23:1685-93. doi:10.1096/fj.08-126458

68. Loomis WH, Namiki S, Ostrom RS, Insel PA, Junger WG. Hypertonic stress increases $\mathrm{T}$ cell interleukin-2 expression through a mechanism that involves ATP release, P2 receptor, and p38 MAPK activation. J Biol Chem (2003) 278:4590-6. doi:10.1074/jbc.M207868200

69. Filippini A, Taffs RE, Sitkovsky MV. Extracellular ATP in T-lymphocyte activation: possible role in effector functions. Proc Natl Acad Sci US A (1990) 87:8267-71. doi:10.1073/pnas.87.21.8267

70. Manohar M, Hirsh MI, Chen Y, Woehrle T, Karande AA, Junger WG. ATP release and autocrine signaling through $\mathrm{P} 2 \mathrm{X} 4$ receptors regulate gammadelta T cell activation. J Leukoc Biol (2012) 92:787-94. doi:10.1189/jlb.0312121

71. Dubyak GR. P2X7 receptor regulation of non-classical secretion from immune effector cells. Cell Microbiol (2012) 14:1697-706. doi:10.1111/ cmi. 12001

72. Franchi L, Kanneganti TD, Dubyak GR, Nunez G. Differential requirement of P2X7 receptor and intracellular $\mathrm{K}+$ for caspase- 1 activation induced by intracellular and extracellular bacteria. J Biol Chem (2007) 282:18810-8. doi:10.1074/jbc.M610762200

73. Gudipaty L, Munetz J, Verhoef PA, Dubyak GR. Essential role for Ca2+ in regulation of IL-1beta secretion by P2X7 nucleotide receptor in monocytes, macrophages, and HEK-293 cells. Am J Physiol Cell Physiol (2003) 285:C286-99. doi:10.1152/ajpcell.00070.2003

74. Qu Y, Ramachandra L, Mohr S, Franchi L, Harding CV, Nunez G, et al. P2X7 receptor-stimulated secretion of $\mathrm{MHC}$ class II-containing exosomes requires the ASC/NLRP3 inflammasome but is independent of caspase-1. J Immunol (2009) 182:5052-62. doi:10.4049/jimmunol.0802968

75. Idzko M, Ferrari D, Eltzschig HK. Nucleotide signalling during inflammation. Nature (2014) 509:310-7. doi:10.1038/nature13085

76. Volonte C, Apolloni S, Skaper SD, Burnstock G. P2X7 receptors: channels, pores and more. CNS Neurol Disord Drug Targets (2012) 11:705-21. doi:10.2174/187152712803581137

77. Cheneval D, Ramage P, Kastelic T, Szelestenyi T, Niggli H, Hemmig R, et al. Increased mature interleukin-1beta (IL-1beta) secretion from THP-1 cells induced by nigericin is a result of activation of p45 IL-1beta-converting enzyme processing. J Biol Chem (1998) 273:17846-51. doi:10.1074/ jbc. 273.28.17846

78. Netea MG, Simon A, van de Veerdonk F, Kullberg BJ, Van der Meer JW, Joosten LA. IL-1beta processing in host defense: beyond the inflammasomes. PLoS Pathog (2010) 6:e1000661. doi:10.1371/journal. ppat.1000661

79. Bergsbaken T, Fink SL, Cookson BT. Pyroptosis: host cell death and inflammation. Nat Rev Microbiol (2009) 7:99-109. doi:10.1038/nrmicro2070

80. Jacobs SR, Damania B. NLRs, inflammasomes, and viral infection. J Leukoc Biol (2012) 92:469-77. doi:10.1189/jlb.0312132

81. Lamkanfi M, Dixit VM. Inflammasomes and their roles in health and disease. Ann Rev Cell Dev Biol (2012) 28:137-61. doi:10.1146/ annurev-cellbio-101011-155745

82. Miller CM, Boulter NR, Fuller SJ, Zakrzewski AM, Lees MP, Saunders BM, et al. The role of the P2X(7) receptor in infectious diseases. PLoS Pathog (2011) 7:e1002212. doi:10.1371/journal.ppat.1002212

83. Morandini AC, Savio LE, Coutinho-Silva R. The role of $\mathrm{P} 2 \mathrm{X} 7$ receptor in infectious inflammatory diseases and the influence of ectonucleotidases. Biomed J (2014) 37:169-77. doi:10.4103/2319-4170.127803

84. Franco-Martinez S, Nino-Moreno P, Bernal-Silva S, Baranda L, Rocha-Meza M, Portales-Cervantes L, et al. Expression and function of the purinergic receptor P2X7 in patients with pulmonary tuberculosis. Clin Exp Immunol (2006) 146:253-61. doi:10.1111/j.1365-2249.2006.03213.x

85. Wu G, Zhao M, Gu X, Yao Y, Liu H, Song Y. The effect of P2X7 receptor 1513 polymorphism on susceptibility to tuberculosis: a meta-analysis. Infect Genet Evol (2014) 24:82-91. doi:10.1016/j.meegid.2014.03.006

86. Xiao J, Sun L, Yan H, Jiao W, Miao Q, Feng W, et al. Metaanalysis of P2X7 gene polymorphisms and tuberculosis susceptibility. FEMS Immunol Med Microbiol (2010) 60:165-70. doi:10.1111/j.1574-695X.2010.00735.x

87. Yi L, Cheng D, Shi H, Huo X, Zhang K, Zhen G. A meta-analysis of P2X7 gene-762T/C polymorphism and pulmonary tuberculosis susceptibility. PLoS One (2014) 9:e96359. doi:10.1371/journal.pone.0096359

88. Darville T, Welter-Stahl L, Cruz C, Sater AA, Andrews CW Jr, Ojcius DM. Effect of the purinergic receptor $\mathrm{P} 2 \mathrm{X} 7$ on Chlamydia infection in cervical epithelial cells and vaginally infected mice. J Immunol (2007) 179:3707-14. doi:10.4049/jimmunol.179.6.3707

89. Marques-da-Silva C, Chaves MM, Chaves SP, Figliuolo VR, MeyerFernandes JR, Corte-Real S, et al. Infection with Leishmania amazonensis upregulates purinergic receptor expression and induces host-cell susceptibility to UTP-mediated apoptosis. Cell Microbiol (2011) 13:1410-28. doi:10.1111/j.1462-5822.2011.01630.x

90. Marques-da-Silva C, Chaves MM, Rodrigues JC, Corte-Real S, CoutinhoSilva R, Persechini PM. Differential modulation of ATP-induced P2X7associated permeabilities to cations and anions of macrophages by infection with Leishmania amazonensis. PLoS One (2011) 6:e25356. doi:10.1371/ journal.pone.0025356

91. Lees MP, Fuller SJ, McLeod R, Boulter NR, Miller CM, Zakrzewski AM, et al. P2X7 receptor-mediated killing of an intracellular parasite, Toxoplasma gondii, by human and murine macrophages. J Immunol (2010) 184:7040-6. doi:10.4049/jimmunol.1000012

92. Miller CM, Zakrzewski AM, Ikin RJ, Boulter NR, Katrib M, Lees MP, et al. Dysregulation of the inflammatory response to the parasite, Toxoplasma gondii, in P2X7 receptor-deficient mice. Int J Parasitol (2011) 41:301-8. doi:10.1016/j.ijpara.2010.10.001

93. Paoletti A, Raza SQ, Voisin L, Law F, Pipoli da Fonseca J, Caillet M, et al. Multifaceted roles of purinergic receptors in viral infection. Microbes Infect (2012) 14:1278-83. doi:10.1016/j.micinf.2012.05.010 
94. Lee BH, Hwang DM, Palaniyar N, Grinstein S, Philpott DJ, Hu J. Activation of $\mathrm{P} 2 \mathrm{X}(7)$ receptor by ATP plays an important role in regulating inflammatory responses during acute viral infection. PLoS One (2012) 7:e35812. doi:10.1371/journal.pone.0035812

95. Lamas Longarela O, Schmidt TT, Schoneweis K, Romeo R, Wedemeyer H, Urban S, et al. Proteoglycans act as cellular hepatitis delta virus attachment receptors. PLoS One (2013) 8:e58340. doi:10.1371/journal.pone.0058340

96. Taylor JM, Han Z. Purinergic receptor functionality is necessary for infection of human hepatocytes by hepatitis delta virus and hepatitis B virus. PLoS One (2010) 5:e15784. doi:10.1371/journal.pone.0015784

97. Manzoor S, Idrees M, Ashraf J, Mehmood A, Butt S, Fatima K, et al. Identification of ionotrophic purinergic receptors in Huh-7 cells and their response towards structural proteins of HCV genotype 3a. Virol J (2011) 8:431. doi:10.1186/1743-422X-8-431

98. Ashraf W, Manzoor S, Ashraf J, Ahmed QL, Khalid M, Tariq M, et al. Transcript analysis of P2X receptors in PBMCs of chronic HCV patients: an insight into antiviral treatment response and HCV-induced pathogenesis. Viral Immunol (2013) 26:343-50. doi:10.1089/vim.2013.0044

99. Zandberg M, van Son WJ, Harmsen MC, Bakker WW. Infection of human endothelium in vitro by Cytomegalovirus causes enhanced expression of purinergic receptors: a potential virus escape mechanism? Transplantation (2007) 84:1343-7. doi:10.1097/01.tp.0000287598.25493.a5

100. Pacheco PA, Faria RX, Ferreira LG, Paixao IC. Putative roles of purinergic signaling in human immunodeficiency virus-1 infection. Biol Direct (2014) 9:21. doi:10.1186/1745-6150-9-21

101. Barat C, Gilbert C, Imbeault M, Tremblay MJ. Extracellular ATP reduces HIV-1 transfer from immature dendritic cells to CD4+ T lymphocytes. Retrovirology (2008) 5:30. doi:10.1186/1742-4690-5-30

102. Hazleton JE, Berman JW, Eugenin EA. Purinergic receptors are required for HIV-1 infection of primary human macrophages. J Immunol (2012) 188:4488-95. doi:10.4049/jimmunol.1102482

103. Orellana JA, Velasquez S, Williams DW, Saez JC, Berman JW, Eugenin EA. Pannexin1 hemichannels are critical for HIV infection of human primary CD4+ T lymphocytes. J Leukoc Biol (2013) 94:399-407. doi:10.1189/ jlb.0512249

104. Seror C, Melki MT, Subra F, Raza SQ, Bras M, Saidi H, et al. Extracellular ATP acts on P2Y2 purinergic receptors to facilitate HIV-1 infection. J Exp Med (2011) 208:1823-34. doi:10.1084/jem.20101805

105. Swartz TH, Esposito AM, Durham ND, Hartmann BM, Chen BK. P2Xselective purinergic antagonists are strong inhibitors of HIV-1 fusion during both cell-to-cell and cell-free infection. J Virol (2014) 88:11504-15. doi:10.1128/JVI.01158-14

106. Nikolova M, Carriere M, Jenabian MA, Limou S, Younas M, Kok A, et al. CD39/adenosine pathway is involved in AIDS progression. PLoS Pathog (2011) 7:e1002110. doi:10.1371/journal.ppat.1002110

107. Sorrell ME, Hauser KF. Ligand-gated purinergic receptors regulate HIV-1 tat and morphine related neurotoxicity in primary mouse striatal neuron-glia co-cultures. J Neuroimmune Pharmacol (2014) 9:233-44. doi:10.1007/ s11481-013-9507-z

108. Tovar YRLB, Kolson DL, Bandaru VV, Drewes JL, Graham DR, Haughey NJ. Adenosine triphosphate released from HIV-infected macrophages regulates glutamatergic tone and dendritic spine density on neurons. J Neuroimmune Pharmacol (2013) 8:998-1009. doi:10.1007/s11481-013-9471-7

109. Jolly C, Kashefi K, Hollinshead M, Sattentau QJ. HIV-1 cell to cell transfer across an Env-induced, actin-dependent synapse. J Exp Med (2004) 199:283-93. doi:10.1084/jem.20030648

110. Hubner W, Chen P, Del Portillo A, Liu Y, Gordon RE, Chen BK. Sequence of human immunodeficiency virus type 1 (HIV-1) Gag localization and oligomerization monitored with live confocal imaging of a replication-competent, fluorescently tagged HIV-1. J Virol (2007) 81:12596-607. doi:10.1128/ JVI.01088-07

111. Marin M, Du Y, Giroud C, Kim JH, Qui M, Fu H, et al. High-throughput HIV-cell fusion assay for discovery of virus entry inhibitors. Assay Drug Dev Technol (2015) 13:155-66. doi:10.1089/adt.2015.639

112. Giroud C, Marin M, Hammonds J, Spearman P, Melikyan GB. P2X1 receptor antagonists inhibit HIV-1 fusion by blocking virus-coreceptor interactions. $J$ Virol (2015) 89:9368-82. doi:10.1128/JVI.01178-15
113. Ali Z, Laurijssens B, Ostenfeld T, McHugh S, Stylianou A, Scott-Stevens P, et al. Pharmacokinetic and pharmacodynamic profiling of a $\mathrm{P} 2 \mathrm{X} 7$ receptor allosteric modulator GSK1482160 in healthy human subjects. $\mathrm{Br} J$ Clin Pharmacol (2013) 75:197-207. doi:10.1111/j.1365-2125.2012.04320.x

114. Arulkumaran N, Unwin RJ, Tam FW. A potential therapeutic role for P2X7 receptor (P2X7R) antagonists in the treatment of inflammatory diseases. Expert Opin Investig Drugs (2011) 20:897-915. doi:10.1517/13543784.2011 .578068

115. Paoletti A, Raza SQ, Voisin L, Law F, Caillet M, Martins I, et al. Editorial: pannexin-1 - the hidden gatekeeper for HIV-1. J Leukoc Biol (2013) 94:390-2. doi:10.1189/jlb.0313148

116. Velasquez S, Eugenin EA. Role of Pannexin-1 hemichannels and purinergic receptors in the pathogenesis of human diseases. Front Physiol (2014) 5:96. doi:10.3389/fphys.2014.00096

117. Graziano F, Desdouits M, Garzetti L, Podini P, Alfano M, Rubartelli A, et al. Extracellular ATP induces the rapid release of HIV-1 from virus containing compartments of human macrophages. Proc Natl Acad Sci U S A (2015) 112:E3265-73. doi:10.1073/pnas.1500656112

118. Allers K, Fehr M, Conrad K, Epple HJ, Schurmann D, Geelhaar-Karsch A, et al. Macrophages accumulate in the gut mucosa of untreated HIV-infected patients. J Infect Dis (2014) 209:739-48. doi:10.1093/infdis/jit547

119. Shive CL, Mudd JC, Funderburg NT, Sieg SF, Kyi B, Bazdar DA, et al. Inflammatory cytokines drive $\mathrm{CD} 4+\mathrm{T}$-cell cycling and impaired responsiveness to interleukin 7: implications for immune failure in HIV disease. J Infect Dis (2014) 210:619-29. doi:10.1093/infdis/jiu125

120. Liu CM, Osborne BJ, Hungate BA, Shahabi K, Huibner S, Lester R, et al. The semen microbiome and its relationship with local immunology and viral load in HIV infection. PLoS Pathog (2014) 10:e1004262. doi:10.1371/journal. ppat. 1004262

121. Guo H, Gao J, Taxman DJ, Ting JP, Su L. HIV-1 infection induces interleukin-1beta production via TLR8 protein-dependent and NLRP3 inflammasome mechanisms in human monocytes. J Biol Chem (2014) 289:21716-26. doi:10.1074/jbc.M114.566620

122. Galloway NL, Doitsh G, Monroe KM, Yang Z, Munoz-Arias I, Levy DN, et al. Cell-to-cell transmission of HIV-1 is required to trigger pyroptotic death of lymphoid-tissue-derived CD4 T cells. Cell Rep (2015) 12:1555-63. doi:10.1016/j.celrep.2015.08.011

123. Doitsh G, Cavrois M, Lassen KG, Zepeda O, Yang Z, Santiago ML, et al. Abortive HIV infection mediates CD4 T cell depletion and inflammation in human lymphoid tissue. Cell (2010) 143:789-801. doi:10.1016/j. cell.2010.11.001

124. Doitsh G, Galloway NL, Geng X, Yang Z, Monroe KM, Zepeda O, et al. Cell death by pyroptosis drives CD4 T-cell depletion in HIV-1 infection. Nature (2014) 505:509-14. doi:10.1038/nature12940

125. Monroe KM, Yang Z, Johnson JR, Geng X, Doitsh G, Krogan NJ, et al. IFI16 DNA sensor is required for death of lymphoid CD4 T cells abortively infected with HIV. Science (2014) 343:428-32. doi:10.1126/science.1243640

126. Steele AK, Lee EJ, Manuzak JA, Dillon SM, Beckham JD, McCarter MD, et al. Microbial exposure alters HIV-1-induced mucosal CD4+ T cell death pathways ex vivo. Retrovirology (2014) 11:14. doi:10.1186/1742-4690-11-14

127. Jorgensen I, Miao EA. Pyroptotic cell death defends against intracellular pathogens. Immunol Rev (2015) 265:130-42. doi:10.1111/imr.12287

128. Alvarez RA, Barria MI, Chen BK. Unique features of HIV-1 spread through T cell virological synapses. PLoS Pathog (2014) 10:e1004513. doi:10.1371/ journal.ppat.1004513

129. Agosto LM, Uchil PD, Mothes W. HIV cell-to-cell transmission: effects on pathogenesis and antiretroviral therapy. Trends Microbiol (2015) 23:289-95. doi:10.1016/j.tim.2015.02.003

130. Agosto LM, Zhong P, Munro J, Mothes W. Highly active antiretroviral therapies are effective against HIV-1 cell-to-cell transmission. PLoS Pathog (2014) 10:e1003982. doi:10.1371/journal.ppat.1003982

131. Fowler BJ, Gelfand BD, Kim Y, Kerur N, Tarallo V, Hirano Y, et al. Nucleoside reverse transcriptase inhibitors possess intrinsic anti-inflammatory activity. Science (2014) 346:1000-3. doi:10.1126/science.1261754

132. Carroll WA, Donnelly-Roberts D, Jarvis MF. Selective P2X(7) receptor antagonists for chronic inflammation and pain. Purinergic Signal (2009) 5:63-73. doi:10.1007/s11302-008-9110-6 
133. Evotec. (2015). Available from: https://www.evotec.com/archive/en/ Press-releases/2008/Evotec-Announces-Phase-I-Initiation-with-P2X7Antagonist/1527/1

134. Duplantier AJ, Dombroski MA, Subramanyam C, Beaulieu AM, Chang SP, Gabel CA, et al. Optimization of the physicochemical and pharmacokinetic attributes in a 6-azauracil series of $\mathrm{P} 2 \mathrm{X} 7$ receptor antagonists leading to the discovery of the clinical candidate CE-224,535. Bioorg Med Chem Lett (2011) 21:3708-11. doi:10.1016/j.bmcl.2011.04.077

135. Gao M, Wang M, Green MA, Hutchins GD, Zheng QH. Synthesis of [(11)C]GSK1482160 as a new PET agent for targeting P2X7 receptor. Bioorg Med Chem Lett (2015) 25:1965-70. doi:10.1016/j. bmcl.2015.03.021

136. Felson DT, LaValley MP. The ACR20 and defining a threshold for response in rheumatic diseases: too much of a good thing. Arthritis Res Ther (2014) 16:101. doi:10.1186/ar4428
137. De Clercq E. Suramin: a potent inhibitor of the reverse transcriptase of RNA tumor viruses. Cancer Lett (1979) 8:9-22. doi:10.1016/0304-3835(79)90017-X

138. De Clercq E. Suramin in the treatment of AIDS: mechanism of action. Antiviral Res (1987) 7:1-10. doi:10.1016/0166-3542(87)90034-9

Conflict of Interest Statement: The authors declare that the research was conducted in the absence of any commercial or financial relationships that could be construed as a potential conflict of interest.

Copyright (c) 2015 Swartz, Dubyak and Chen. This is an open-access article distributed under the terms of the Creative Commons Attribution License (CC BY). The use, distribution or reproduction in other forums is permitted, provided the original author(s) or licensor are credited and that the original publication in this journal is cited, in accordance with accepted academic practice. No use, distribution or reproduction is permitted which does not comply with these terms. 